\title{
RIGLYNE VIR PASTORALE HUWELIKSORG BINNE DIE KONTEKS VAN GEMEENTE-OPBOU
}

\author{
E.J. Tiemensma \\ C.J.H. Venter \\ Departement Diakoniologie \\ Potchefstroomse Universiteit vir CHO \\ POTCHEFSTROOM
}

\begin{abstract}
The aim of this article is to examine the distinct character of pastorally-orientated marriage counselling in contrast to psychologicalby-orientated mamige counselling. The conclusions arrived at is that whereas pastoral marrige counselling aims at the edification of the congregation certain other marriage enrichment programmes do not provide adequate Scripturally-founded perspectives. The inherent character of marriage as revealed in Scripture is considered and an attempt is made to extract certain guidelines for pastoral marriage counselling. The focal point, however, remains the edification of the congregation by the pastorate. Bearing this in mind basic outlines from Scripture are given within which pastoral counselling can function in practice.
\end{abstract}

\section{INLEIDEND}

In hierdie artikel word gepoog om die eiesoortige aard van huweliksorg te omlyn en aan te toon hoe huweliksorg geïntegreerd met gemeente-opbou behoort plaas te vind. Pastorale huweliksorg word behandel binne die konteks van gemeente-opbou in onderskeiding van huweliksverryking binne psigologiese konteks.

\subsection{Begripsomlyning en metode}

Vir die doeleindes van hierdie artikel word die begrip huweliksverryking gebruik vir die psigologies-georiënteerde perspektief op die huwelik en huweliksorg dui op die pastorale beginsels uit die Woord van God waarvolgens egpare versorg moet word. Die navorsingsmetode ten einde die eie aard van huweliksorg binne die konteks van gemeente-opbou te omskryf, is primêr 'n literatuurstudie. Deur analise en sintese is die gegewens rondom die begrippe huweliksveryking en huweliksorg gekeur en gerangskik om in die besondere opset van hierdie artikel in te pas. 


\section{DIE EIESOORTIGE AARD VAN HUWELJKSORG}

Die vraag na die eie aard van huweliksorg binne die konteks van gemeente-opbou, moet veral teen die agtergrond van die gedagte van huweliksverryking gesien word. Volgens Otto (1976:11) word die term huweliksverryking gebruik vir 'n "nuwe beweging" wat sedert 1961 tot 'n "lusty stature" ontwikkel het. Huweliksverryking is 'n "nuwe beweging" in dié opsig dat die klem nie op hulpverlening aan huwelikspare met probleme geplaas word nie, maar daarop om 'n goeie huwelik te verbeter en egpare tot groter geluk in hulle huweliksverhouding te stimuleer (Otto, 1976:13; Barnard, 1987:13). Die aksentverskuiwing van krisisversorging na voorkomingsversorging vind sy neerslag in verrykingsprogramme wat die verbetering van 'n goeie huwelik veral aan die volgende aspekte koppel: "... actualizing human potential, humanistic psychology and effective education" (Otto, 1976:13). Binne die konteks van psigologiese aspekte soos potensiaalontginning het hierdie verrykingsprogramme ten doel om die verhoudingsinteraksie tussen man en vrou te verryk, te versterk en te verbeter (Clinebell, 1970:25-33; vgl. ook Louw, 1986:260).

Die gedagte van huweliksverryking lê die vraag na die eie aard van huweliksorg voor die deur van die huwelikspastoraat en daar moet nagegaan word of huweliksverryking in die huwelikspastoraat met vrug toegepas kan word. In onderskeiding van huweliksverryking in psigologiese konteks, beskou Pieterse (1977:50-52; 1983:18-19) die gedagte van huweliksverryking in die huwelikspastoraat as positief, mits huweliksverryking altyd by geloofsverdieping begin. Louw (1986:262) integreer die gedagte van huweliksverryking in die pastorale huweliksorg met die voorbehoud dat die teologie moet uitspel wat onder die begrippe voorkoming en groei verstaan word. Binne die konteks van ' $n$ onderskeiding tussen huweliksverryking as 'n psigologiese aangeleentheid en huweliksverryking as 'n pastorale aangeleentheid, word afsonderlik oor huweliksorg besin (vgl. Pieterse, 1977:41-56; Louw, 1983:224-229). Die vraag na die eie aard van huweliksorg en of huweliksverryking in die huwelikspastoraat binne die raamwerk van gemeente-opbou geïntegreer kan word, word egter nie in besonderhede deur genoemde outeurs behandel nie.

Gemeente-opbou is 'n tema wat in 'n groot mate die skopus van ondersoek van al die fasette van die Diakoniologie geword het (Venter, 1986:5-6; Rossouw, 1988:14-15). Tans word baie oor die taak van die Diakoniologie met die oog op die opbou van die gemeente besin, maar die aandag word nie spesifiek aan huweliksorg binne gemeenteopbou gewy nie. Ook word nie genoegsaam aandag gegee aan die wyse waarop huweliksorg geïntegreerd met gemeente-opbou behoort plaas te vind nie. Louw (1985a:170; 1986:271-272) meen dat huweliksverryking as pastorale aangeleentheid ' $n$ absolute vereiste vir gemeente-opbou is. In onderskeiding van huweliksverryking binne psigologiese konteks, kom die eie aard van huweliksorg binne die konteks van gemeente- 
opbou egter nie sterk aan die orde nie.

Teen die agtergrond van 'n verkenning van die psigologies-georiēnteerde perspektief op huweliksverryking, is die primêre fokus van hierdie artikel om vanuit die Skrif riglyne te bied vir pastorale huweliksorg binne die konteks van gemeente-opbou. Ten slotte word bepaalde aanwysers vir die praktyk gebied. Binne die bestek van hierdie artikel word nie primer gekonsentreer op 'n volledige uiteensetting van 'n praktykmodel vir huweliksorg binne gemeente-opbou nie.

\section{HUWELIKSVERRYKING BINNE PSIGOLOGIESE PERSPEKTIEF}

Die doel van huweliksverryking is om 'n goeie huwelik te verbeter. Om hierdie doel te bereik, is die verrykingsprogramme vanuit psigologiese perspektief op die volgende veronderstelling geskoei: "... the growth ethos and the human potentialities movement" (Otto, 1976:11). Die begrip groei, wat deur verskeie psigologiese en psigoterapeutiese gesigspunte beìnvloed is, is 'n basiese komponent van die psigologies-georieznteerde verrykingsprogramme. Dat die begrip groei beslis beīnvloed is deur verskeic psigologiese vertrekpunte, blyk duidelik uit die term growth counselling wat deur Clinebell gemunt is. Die begrip groei in die growth counselling is onder meer deur die gesigspunte van die Gestalt therapy en die transactional analysis beïnvloed (Clinebell, 1982:46). Die verrykingsprogramme van die Gestalt therapy en die transactional analysis word nou verken, asook hulle bydrae tot die teorievorming van die growth counselling.

\subsection{Die Gestalt therapy se program vir huweliksverryking}

Die Gestalt therapy definieer die huwelik as 'n dialoog tussen twee individue (Zinker \& Leon, 1976:144,146). Huweliksverryking het ten doel om die dialoogverhouding in die lig van die volgende perspektief te verbeter: "My relationship with others can be only as deep and authentic as is my relationship with my own inner centre. Increased selfawareness is a prerequisite to a more need-satisfying relation with others" (Clinebell, 1981:171,175).

Die Gestalt therapy se program vir verryking is ten opsigte van groei in die dialoogverhouding veral op die volgende uitgangspunte gebaseer:

- Die bewuswording van die inner centre se behoeftes en die aanvulling van mekaar se behoeftes (Zinker \& Leon, 1976:144,146,151).

- In die dialoogverhouding word groei deur kommunikasie ontsluit. Kommunikasie is 
'n sleutelbegrip waardeur huweliksgenote bewus word van mekaar se innerlike behoeftes.

\subsection{Die transactional analysis se program vir huweliksverryking}

Die transactional analysis se program vir verryking beoog die daarstelling van 'n raamwerk "within which we can understand how and why we act the way we do" (Capers, 1976:158). Hierdie raamwerk moet teen die agtergrond van die transactional analysis se persoonlikheidsbeskouing gesien word. Volgens die transactional analysis "verstaan" iemand driedimensioneel ten opsigte van sy persoonlikheid; naamlik in verhouding tot die ouer-, die volwasse- en die kind-egostaat (ego states).

Die verrykingsprogram om groei in die huweliksverhouding te stimuleer, bestaan uit die volgende:

- Terapeutiese hu!p om egpare te help verstaan hoe en waarom mense in verhouding tot die verskille ide egostate optree soos hulle optree.

- Terapeutiese leiding om die volwasse-egostaat te herken en te leer beheer met die oog op groei in die huweliksverhouding.

\section{Die growth counseling se program vir huweliksverryking}

Die grow'th counselling gaan van die veronderstelling uit dat in elke huweliksverhouding 'n latente groeipotensiaal skuil. Die growth counselling se benadering is dat groei plaasvind binne ' $n$ verhouding wat op liefde en openhartigheid gegrond is. Die doel van verryking is die ontsluiting van die groeipotensiaal ten einde die intimiteit in die huweliksverhouding te verbeter en te versterk (Clinebell, 1982:42). Volgens Clinebell (1982:55) is die voorwaarde vir groei in die volgende uitgangspunte vervat:

- Die vermoë om mekaar te versorg deur middel van liefde en aanvaarding.

- Openhartige konfrontasie met die oog op selfinsig en gedragsverandering.

- Verdiepte kommunikasie en betrokkenheid by mekaar met die oog op behoeftebevrediging wat die boustene vir die skep van 'n intimiteitsverhouding is.

\subsection{Die komponente van huweliksverryking in psigologiese konteks}

Met verwysing na die verrykinsprogramme van die Gestalt therapy en die transactional analysis en hulle bydrae tot die ontwikkeling van die groeimodel by die growth 
counseling, kan die volgende komponente as grondliggend onderskei word: potensiaalontginning, persoonlike kwaliteite, kommunikasie en behoeftebevrediging. Die onmiddellike doel van huweliksverryking kan in die lig van bogemelde komponent soos volg beskryf word:

- Die groei na 'n diepteverhouding deur die ontginning van die potensiaal wat in die bestaande verhouding aanwesig is.

- Die verbetering van die emosionele kwaliteit van die huwelik deur die ontsluiting van persoonlikheidspotensiaal.

- Die ontginning van 'n verhouding in diepte deur kommunikasie.

- Die versterking van die intimiteit in die huweliksverhouding deur die bevrediging van wedersydse behoeftes.

Die uiteindelike doel van huweliksverryking kan omskryf word as die ontsluiting van groei met die oog op die versterking van die emosionaliteit in ' $n$ intimiteitsverhouding. Vir die bereiking van hierdie doel word primer vanuit die potensiaal van die bestaande verhouding gewerk. Huweliksverryking in psigologiese konteks is uitsluitlik toegespits op die verbetering van die verhoudingsdinamiek in die interpersoonlike verhouding tussen man en vrou. (Vgl. Louw, 1986:260.)

\subsection{Die metode van verryking en die eie aard van huweliksorg}

Die gedagte van verryking binne psigologiese konteks is uitsluitlik gekoppel aan die ontginning van die potensiaal wat latent in 'n bestaande verhouding opgesluit le. (Louw, 1985a:159,163; vgl. ook Pieterse, 1977:51.) Binne die konteks van die ontginning van die potensiaal word in die psigologies-georiënteerde verrykingsprogramme hoofsaaklik op aspekte soos intimiteit, kommunikasie, gedragsverandering en behoeftebevrediging gefokus. Vanuit die verkenning van die psigologies-georiënteerde verrykingsprogramme blyk dit dat die primêre vertrekpunt nie eksplisiet God se opdrag aan die huweliksgenote en sy bedoeling met die huwelik is nie, maar die ontginning van menslike potensiaal en persoonlikheidspotensiaal.

Met die oog op die omskrywing van huweliksorg binne die konteks van gemeenteopbou, is die vertrekpunt nie die sondige menslike potensiaal nie, maar die versorging van huweliksgenote as nuwe mense in Christus, ten einde bulle te begelei op die weg van beantwoording aan God se dcel met die huwelik. Metodologies word hiermee 'n keuse gemaak vir die bestudering van huweliksorg, naamlik dat die vaste grondslae van God se Woord nie verlaat mag word nie.

Die uitgangspunt van hierdie studie is dat die Diakoniologie, met die oog op 
gemeente-opbou deur die pastoraat, die bestudering van God se Woord as taak het. Op grond van hierdie uitgangspunt en omdat die psigologies-georiënteerde verrykingsprogramme nie genoegsame perspektiewe vir die omskrywing van pastorale huweliksorg bied nie, word nou na die huvelik in die lig van die Skrif gekyk ten einde riglyne vir huweliksorg te omskryf.

\section{DIE AARD VAN DIE HUWELIK EN HUWELIKSORG IN DIE LIG VAN DIE SKRIF}

Die Woord van God openbaar dat die huwelik deur God ingestel is. Ten einde riglyne vir huweliksorg daar te stel, word aan die volgende aspekte aandag gegee: die opdrag aan huweliksgenote soos in God se skeppingswerk gegrond; die bedoeling met die huwelik in God se skeppingswerk; die versoenende en oorwinnende saamlewe in die huwelik.

\subsection{Die opdrag aan huweliksgenote soos in God se skeppingswerk gegrond}

Veral in die Skrifgedeeltes Genesis 1:26-28; 2:7-25 en Matteus 19:4-6 word geopenbaar dat die huwelik in volle rykdom deur God ingestel is. Die omskrywing van die huwelik as ' $n$ instelling van God is met die volgende drie sake verbind: man en vrou is na die beeld van God geskape, die vereniging van man en vrou is ' $n$ samevoeging van God en die huwelik is 'n verbondsgemeenskap.

- Die Skrif openbaar in Genesis 2:22 dat die man-vrouverhouding 'n skeppingsdaad van God was. In Christus se verwysing daarna in Matteus 19:4 staan die manvrouverhouding in samehang tot die skepping van die mens volgens Genesis 1:27: "... as beeld van God het Hy die mens geskep, man en vrou het Hy hulle geskep". As onder "die beeld van God" veral skadubeeld verstaan word, beteken dit dat die mens God se heerlikheid, veral sy heerskappy, in persoonlike gemeenskap met Hom moet afskadu (Helberg, 1976:63; vgl. ook Vriezen, 1974:448). Die opdrag aan huweliksgenote is om God se heer-likheid te weerkaats deur sy heerskappy en dit op die konkrete vlak van die man-vrouverhouding te erken.

- Die vereniging van man en vrou tot "een word" (Gen. 2:24), word deur Christus in Matteus 19:5,6 as die "samevoeging deur God" verklaar. Die begrip saamvoeg

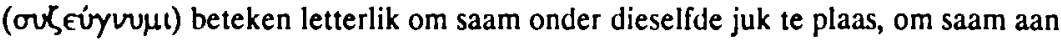
verantwoordelikheid te dra (Link \& Brown, 1978:1162-1164). Dit is God se wil dat man en vrou in gemeenskap met mekaar sal lewe en sy opdrag sal uitlewe. 
- In die Ou Testament is die huwelik 'n verbondsgemeenskap wat ' $n$ besondere verantwoordelikheid impliseer (Louw, 1983:64-65). Maleagi 2:14 verwys byvoorbeeld na die huwelik as 'n verbondsgemeenskap waarby God self as getuie ingeroep is. Die huweliksverbond ( $\Pi$ ! $\beta$ ) veronderstel 'n lewensverantwoordelikheid in gehoorsaamheid aan die norm wat God vir die huwelik stel.

Dit is God se wil dat man en vrou in gemeenskap met mekaar sal lewe (vgl. Brillenburg Wurth, 1955:56). Die opdrag aan huweliksgenote, soos in God se skeppingswerk gegrond, kan soos volg omskryf word: om in erkenning van God se heerskappy die huwelikslewe volgens sy norm in te rig.

\section{Die bedoeling met die buwelik in God se skeppingswerk}

God se bedoeling met die huwelik kom in die skepping van die mens as man-wees en vrou-wees tot openbaring (Gen. 1:27). Die huwelik is 'n geskape samesyn (tweeeenheid) en op grond van die volgende Skrifgegewens kan die huwelik as 'n saam-wees in wedersydse aanvulling beskryf word:

- Die Hebreeuse woord vir man en vrou in Genesis 2:23 gee uitdrukking aan die aanvullende hoedanighede van man en vrou tot mekaar: ה (vrou) word deur die toevoeging van die vroulike uitgang by kompleetmaking van mekaar, aanvullend op mekaar aangewys (Van der Walt, 1987:5).

- God het die vrou as hulp alleen-wees maak die Here ruimte vir gemeenskap en aanvulling wat op lewensontplooiing en lewensvolheid gerig is (Jeweth, 1976:124).

- Die huwelik is die vereniging van die lewens van twee mense in een lewensgemeenskap. Hierdie vereniging staan in Genesis 2:24a in verband met die huweliksliefde, waardeur die huwelikseenheid bewerk en versterk word (Linde, 1988:20). Gesmee deur die band van liefde en trou, is dit God se bedoeling dat die huweliksverbintenis 'n lewensgemeenskap van hegte toewyding aan mekaar sal wees.

- Die innige verbondenheid tussen man en vrou vind sy afronding in liggaamlike eenwording. Liggaamlike eenwording is die kulminasie van die liefde tussen man en vrou en die Hebreeuse woord $y_{7}$ ? in Genesis $2: 24 \mathrm{~b}$, het in hierdie verband die betekenis van een-persoon-word (Adams, 1979:132). In wedersydse oorgawe van liggaam en gees word die huwelikseenheid gebou (Mack, 1977:97-98; Adams, 1984:27). 
Die Skrif openbaar dat man en vrou se saam-wees 'n Goddelike bedoeling het, naamlik om mekaar aan te vul sodat hulle in gehoorsaamheid aan die opdrag van God, afsonderlik en gesamentlik, weer volkome kan wees.

\subsection{Versoenende saamlewe in die huwelik}

Man en vrou se saam-wees in wedersydse aanvulling het vanweë die sondeval totaal verander. Vanweẽ die vervreemding in die verhouding tot God, word die aanvullende saam-wees onder meer deur skuld, disharmonie en konflik geskend. Die versoeningswerk deur Christus ontsluit egter 'n nuwe bestaan vir die man en die vrou in die huwelik, omdat Christus die mens in verhouding tot God herstel. Die herstel van die mens in verhouding tot God word onder andere in Efesiërs 2:10 beskrywe. Hierdie perikoop vertoon die sogenaamde uurglasstruktuur, met Efesiërs 2:4, 5a as die knooppunt (Roberts, 1983:56):

- Efesiërs 2:1-3 beskryf die verlede as 'n toestand van doodsheid as gevolg van die ongehoorsaamheid aan God.

- Efesiêrs 2:4,5a is die knooppunt in die uurglasstruktuur: God maak die mens lewend deur die heilswerk van sy Seun.

- Efesiërs 2:5b-10 beklemtoon die feit dat wie God se heil in Christus deelagtig geword het, daarvolgens moet lewe.

Die nuwe lewenswandel is ook allesbepalend vir die verhouding ten opsigte van die persoonlike lewe. Die nuwe lewenswandel wat vir die man en die vrou in die huwelik ontsluit word, is om versoenend met mekaar te leef. In die lig hiervan verkry die manvrouverhouding besondere reliëf as dit gesien word teen die agtergrond van die huistafel soos dit in Efesiërs 5:22-23 gestel word:

- Die man is die hoof van die vrou en die vrou is aan die man onderdanig met die oog op 'n gemeenskaplike verbondenheid: "Wees uit eerbied vir Christus aan mekaar onderdanig" (Ef. 5:21). Die algemene reël van Christelike onderdanigheid is allesbepalend vir die huistafel van Efesiërs 5:22-23, waar die verhouding tussen Christus en sy kerk as maatstaf vir die wedersydse aanvulling in die huwelikseenheid dien. In die beginsel van die hoofskap (( $k \in \oint a \bar{\eta} \hat{)}$ ) van die man (liefdevolle, opofferende diens en leiding), word die huwelikseenheid beskerm en deur die geloofsbeslissende onderdanigheid (ن́rotácow) van die vrou, word die huwelikseenheid ondersteun (Marston, 1984:74-77; Floor, 1986:45-54).

- Selfverložnende liefde ( $\alpha y \alpha \dot{r} \eta \eta)$ is 'n opdrag aan die huweliksgenote (Ef. 5:28,33). Die wese van óyádr, met besondere verwysing na Efesiërs 5:28,33, is die vergifnis 
van skuld. Op die konkrete vlak van die man-vrouverhouding, beteken $\alpha$ óórn die bereidheid om mekaar se tekortkominge in die lig van die vryspraak van Christus te sien; om genade aan die huweliksmaat te betoon; om met die gesindheid op te tree wat in Christus Jesus was en om mekaar as mede-erfgename van die ewige lewe te aanvaar.

- Die kwaliteit van die emosionele aard van die liefde wat aan die geslagsdrang gekoppel is, word deur áyórm bepaal. Die kwaliteit van fisiese aangetrokkenheid tot mekaar word deur ayórmn bepaal en die liggaamlike eenwording maak óyórm 'n werklikheid (Wheat, 1988:64-65).

Die versoenende saamlewe rig die huwelikslewe op die rykdom van God se bedoeling daarmee. Die vernuwing van die man-vrouverhouding bou dus op God se oorspronklike skeppingsbedoeling met die huwelik.

\subsection{Oorwinnende saamlewe in die huwelik}

Die gelowige, wat in die verhouding tot God herstel is, word onder meer in 1 Petrus 1:15 vermaan om heilig in lewenswandel te wees. Heilig-wees is die uitleef van die verlossing wat in Christus bestaan. Die saamleef in die huwelik word tot 'n Geesvervulde saamleef verdiep deur die uitleef van die nuwe mens onder die beheersing van die Gees. Die Geesvervulde saamleef in die huwelik kom in die volgende toepassing tot openbaring:

- In 1 Tessalonisense 4:3-8 word die wesensaard van die huwelik nader toegelig as "... elkeen moet met sy vrou heilig en eerbaar saamlewe" (vers 4b). Die "heilig en eerbaar saamlewe" is volgens Baltensweiler (1967:139) 'n nadere verklaring (epeksegeties) by vers 3a: "Dit is die wil van God dat julle heilig moet lewe." Vers 8 is redegewend ten opsigte van die vermaning om eerbaar en heilig saam te lewe: "Wie hierdie voorskrifte verwerp ... verwerp God wat ook sy Gees aan julle gegee het." Heilig en eerbaar saamlewe, moet die uitlewing en belewing daarvan wees dat God sy Gees aan die gelowige gegee het.

- Die gerigtheid op mekaar ("aan mekaar onderdanig wees" - Efesiërs 5:21) is die werk van God Drie-enig deur sy Gees (vgl. Versteeg, 1980:47-48; Louw, 1986:263264). Die Geesvervulde aard yan die huwelik kom hierin tot openbaring, naamlik dat man en vrou dienend en hulpbetonend vir mekaar plek maak binne die ruimte van onderlinge saam-wees. 
- Waar die Heilige Gees die lewe van die gelowige beheer, bring dit ' $n$ verandering in houding, gedrag en gesindheid teweeg. Die vrug van die Gees in die huweliksgenote se lewe berus op grond van Galasiërs 5:19 en 22 op die aflê van die werke van die vlees en die voortbring van liefde en selfbeheersing as die eerste en hoogste vrug van die Gees.

Die uitleef van die nuwe mens-wees in die huwelik, kan omskryf word as die oorwinnende saamleef in die huwelik. Die oorwinnende saamlewe setel in die bereidheid om deur optrede en houding mekaar se belange in 'n heilige en eerbare saamleef te soek.

\section{Samevatting}

In teenstelling met huweliksverryking, waar verryking uitsluitlik gekoppel word aan die potensiaal van die bestaande verhouding, spits huweliksorg toe op die versorging en begeleiding van egpare met die oog op groei in die ontdekking en belewing van God se bedoeling met die huwelik. Die volgende uitgangsgpunte dien as basis vir huweliksorg.

- Die begeleiding van egpare om in gehoorsaamheid aan die opdrag van God hul huweliksverantwoordelikheid en geloofsverantwoordelikheid te verstaan.

- Die begeleiding van egpare, in die konkrete dinamiek van hulle verhouding, op die weg van beantwoording aan die Godgewilde bedoeling met die huwelik.

- Die begeleiding van egpare om die samesyn in die huwelik as versoenende en oorwinnende saamleef te ervaar.

Die gedagte van huweliksverryking bied egter nie genoegsame Skrifgefundeerde perspektiewe sodat daarmee vir huweliksorg binne die konteks van gemeente-opbou volstaan kan word nie. Daarom word vervolgens gefokus op riglyne vir gemeente-opbou waarbinne pastorale huweliksorg kan funksioneer.

\section{RIGLYNE VIR GEMEENTE-OPBOU}

In die opbou van die gemeente deur die pastoraat gaan dit ten diepste om sorg en opbou. Ten opsigte van riglyne vir gemeente-opbou waarbinne pastorale huweliksorg kan funksioneer, is dit noodsaaklik om veral die Nuwe-Testamentiese betekenis van

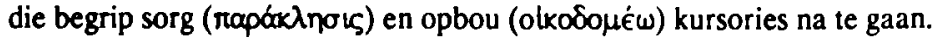

\subsection{Die opbou van die gemeente deur pastorale sorg as paraklese}

Dit is moeilik om 'n enkele begrip in die Skrif uit te sonder wat die veelvormigheid van 
die pastoraat volledig weergee. Die begrip rapáx $\lambda$ no us word egter uitgesonder, omdat dit die dubbele betekenis van verstaan en vertroos het (Firet, 1968:94). Die opbou van die gemeente deur parakletiese versorging, is met die volgende aspekte verbind: ontferming, versoening, troos en opbou.

- Die begrip rapáx $\lambda$ nous het die volgende betekenis: sprekend tot ander in vermaning, of vertroosting rig (Bolkestein, 1964:59). Ten grondslag aan die vermanende of vertroostende spreke lê die ontferming van God. Grondliggend aan die ontferming (oikr $\varphi \mu$ ós) van God, soos byvoorbeeld in Romeine 12:1a beskryf word, lê sy reddende verbondshandelinge. Die ontfermende handeling van die Vader bepaal die motief en gesindheid in die opbou van die gemeente deur die pastoraat.

- Die versoeningswerk van Christus staan sentraal in die pastorale sorg as paraklese. In 2 Korintiërs 5:20 koppel Paulus die versoeningswerk van Christus direk aan die herderlike werk van vermaning (rapak $\lambda \in$ fiv). In die opbou van die gemeente deur die pastoraat as paraklese, word altyd 'n beroep gedoen op dit wat God in Christus gedoen het. Paraklese verbind die gelowige aan Christus en daarom is die doel van opbou deur parakletiese versorging om die sondaarmens op die weg van geloofsverbondenlieid met Christus te begelei. Dit impliseer dat die Woord, wat die versoeningsboudskap bevat, sentraal in die opbou deur die pastoraat moet staan.

- Die opbou van die gemeente deur parakletiese versorging, bied vertroostende bystand. Die vertroostende bystand is, onder meer op grond van Johannes 15:26, met die Persoon en werk van die Heilige Gees (o Mapák $\lambda$ ntos) verbind. Die vertroostende bystand word konkreet in die herderlike bediening van die Woord vergestalt. In die wete dat die Gees self deur die Woord werksaam is, is parakletiese sorg hoopvolle en troosvolle bystand aan die gelowige.

- Binne die gemeenskap van gelowiges (met-mekaar in Christus) het gelowiges 'n verantwoordelikheid vir-mekaar. Op grond van Efesiërs 4:12 hoort die dienswerk van vermaning en vertroosting (ropox $\lambda \in \hat{i}$ ) tot die taak en roeping van die besondere amp en, met besondere verwysing na 1 Tessalonisense 5:11 en Hebreẽrs 3:12$13 ; 10: 24-25$, ook tot die taak van gelowiges onderling.

\subsection{Geloofsgroei as die inhoud van opbou}

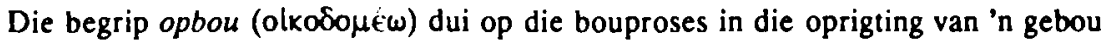
(oixodo $\mu$ ń). Opbou het met die groei van die gemeente te doen en is 'n handeling van God Drie-enig: ophou is gefundeer in die verbondshandeling van God: gebaseer op die kruisversoening en opstandingsoorwinning van Christus en gerealiseer deur die 
inwoning van die Gees (Hendriks, 1987:22-24). Die groei wat binne die opbou van die pastoraat as paraklese bewerkstelling word, is ' $n$ bouproses wat in twee rigtings plaasvind (vgl. Minear, 1977:162-165):

* Veral in Efesiërs 4:12-16 is dit duidelik dat die versorging van die gelowige saamtrek in die geloofsverdieping as deel van die verbondenheid met Christus. Gemeente-opbou deur die pastoraat het ten doel om die groei vanuit en na Christus te begelei.

- Die verbondenheid met Christus mond uit in die gemeenskap van heiliges (communio sanctorum). Geloofsgroei, wat binne die pastoraat as paraklese bewerkstellig word, is binne die onderlinge gemeenskap van gelowiges sigbaar. Die gemeenskap van gelowiges is pastoraal-ekklesiologies die grondvorm in die opbou van die gemeente deur sorg as paraklese.

\section{Samevatting}

In onderskeiding van die gedagte van huweliksverryking, dien die volgende omskrywing as basiese uitgangspunt vir pastorale huweliksorg: die begeleiding van egpare om hulle samesyn, wat in die verhouding tot God veranker is, versoenend en oorwinnend op God se bedoeling met die huwelik te rig. Die volgende uitgangspunte dien as basis vir gemeente-opbou waarbinne pastorale huweliksorg kan funksioneer:

- Die gemeente word deur die pastorale sorg in die gestalte van paraklese opgebou. Toegepas op die pastorale huweliksorg binne gemeente-opbou beteken dit die troosvolle, vermanende en opbouende bediening van die Woord in sy verskillende herderlike gestaltes, op grond waarvan egpare op die weg van geloofsgroei begelei word.

- Pastoraal-ekklesiologies is huweliksorg binne die gemeenskap van gelowiges verbind met die opbou van mekaar (herder-vir-mekaar-wees). Binne die konteks van gemeente-opbou geskied huweliksorg dus nie net met die oog op die versorging van die man-vrouverhouding as die kleinste seldeeltjie in die liggaam van Christus nie, maar sodat die gemeente, toegerus uit die Woord van God, haar verankerdheid in Christus se verlossingswerk kan beleef.

In die lig van bogenoemde verkenning word laastens op riglyne vir die praktyk gekonsentreer. 


\section{RIGLYNE VIR DIE PRAKTYK}

Binne die konteks van die uitgangspunte wat as basis vir huweliksorg en gemeenteopbou dien, word nou afsonderlik ingegaan op fokuspunte, wat as riglyne vir die praktyk van huweliksorg binne gemeente-opbou kan dien.

\subsection{Fokuspunte vir die ontwerp van 'n praktykmodel}

Die volgende fokuspunte vorm die grondslag van 'n praktykmodel vir pastorale huweliksorg binne die konteks van gemeente-opbou: die man-vrouverhouding as 'n twee-eenheid in wedersydse aanvu!ling; die begeleiding ten opsigte van die samesyn in die huwelik; die ontmoeting van mekaar in liggaamlike eenwording en die opbouende betrokkenheid van die gemeenskap van gelowiges by pastorale huweliksorg.

\subsubsection{Die huwelik as 'n twee-eenheid in wedersydse aanvulling}

Die man-vrouverhouding, as ' $n$ twee-eenheid in wedersydse aanvulling, is een van die duidelikste Skrifopenbaringe aangaande die huwelik. Pastorale huweliksorg sal egpare gevolglik begelei ten opsigte van die volgende aspekte van wedersydse aanvulling: die kompleetmaking van mekaar; die taak en optrede van man en vrou met die oog op die huwelikseenheid; trou en liefde in 'n lewensgemeenskap van wedersydse toewyding en die afronding van die twee-eenheid in liggaamlike eenwording.

In die pastorale begeleiding van egpare word op die twee-eenheid in die huwelik gefokus, omdat die twee-eenheid uit twee sondaarmense bestaan wat hulle eie verwagtinge, behoeftes en gedragspatrone in die huwelik indra. Die twee-eenheid kom as fokuspunt ter sprake ten einde egpare die geleentheid te bied om oor hulle eie huweliksverhouding te besin.

\subsection{Begeleiding ten opsigte van die samesyn in die huwelik}

Die pastorale begeleiding van man en vrou setel in die bediening van die versoening. Pastorale huweliksorg het ten doel om man en vrou te begelei ten opsigte van 'n versoenende saamleef, wat onder die beheersing van die Gees vergestalting moet vind. In Kolossense 3:13,14 word die gelowiges vermaan om in ooreenstemming met die nuwe lewe in Christus op te tree: "... vergewe mekaar as die een iets teen die ander het. Soos die Here julle vergewe het, moet julle mekaar ook vergewe". 'n Aspek van begeleiding is die vermaning en bemoediging van man en vrou tot 'n saam-leef wat in 
ooreenstemming met die nuwe lewe in Christus is. Die versoenende saamleef in die huwelik het die volgende konkrete implikasies vir pastorale huweliksorg:

- Begeleiding ten opsigte van vergifnis, om misverstande, ontrou en teleurstellings in die lig van die vryspraak van Christus te sien.

* Begeleiding ten opsigte van vergewensgesindheid: die bereidheid om te vergewe, met ander woorde - vergewe om te vergeet.

- Begeleiding ten opsigte van liefde: om voortdurend aan die huweliksverhouding te werk deur die aanvaarding en die vergifnis van mekaar in selfverloënende liefde.

- Begeleiding ten opsigte van onbaatsugtige selfopoffering: om met geduld, lankmoedigheid en barmhartigheid die belange van die huweliksmaat te soek.

- Begeleiding ten opsigte van nederige selfopoffering: om selfverloënend eerder op moontlikhede as op tekortkominge in die huweliksverhouding te konsentreer.

- Begeleiding ten opsigte van saam-wees binne die ruimte van ware lewensvreugde: liefde, vreugde, vriendelikheid en goedhartigheid as vrug van die Gees.

\subsection{Die ontmoeting van mekaar in liggaamlike eenwording}

Die seksuele aspek het in die lig van God se bedoeling met die huwelik, 'n plek in die pastorale versorging van huwelikspare. Die seksuele aspek het die volgende betekenis vir pastorale huweliksorg:

- Die innige verbondenheid tussen man en vrou vind sy vervulling en afronding in liggaamlike eenwording.

- Geslagsgemeenskap is 'n ontmoeting waar man en vrou mekaar in die diepste van hulle persoon leer ken (Van der Schoot, 1959:127).

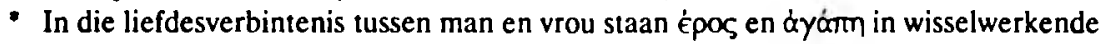
en harmoniese samehang tot mekaar (Getz, 1986:117-127).

6.1.4 Die opbouende betrokkenheid van die gemeenskap van gelowiges by huweliksorg

Die vir-mekaarbeginsel (verbondenheid met mekaar in geloofsverbondenheid) beklee 'n opbouende plek in die pastorale sorg. Die opbouende betrokkenheid van die gemeenskap van gelowiges het die volgende konkrete betekenis vir pastorale huweliksorg:

- Die opbou van die gelowige word konkreet binne die gemeenskap van gelowiges sigbaar. Die onderlinge liefde van gelowiges behoort opbouend by huweliksbou en 
bemoedigend of vermanend by huweliksvervreemding werksaam te wees.

- Die opbouende betrokkenheid van die gemeenskap van gelowiges by huweliksorg word konkreet deur die byeenbring van egpare in groepsverband vergestalt. Dit beteken enersyds dat groepe, binne die konteks van die pastoraal-ekklesiologiese grondslag van huweliksorg, op grond van die een-wees in geloofsverbondenheid met Christus gevorm word. Andersyds is die vermaning en vertroosting, op grond van Efesiërs 4:11-16, aan die Woordgerigte ampsbediening gebonde.

Bogenoemde fokuspunte bepaal laastens die beplanning en strukturering van 'n praktykmodel vir pastorale huweliksorg binne die konteks van gemeente-opbou.

\subsection{Beplanning en strukturering vir die praktyk}

In bogenoemde riglyne vanuit die Skrif is ruimte vir aspekte soos intimiteit, behoeftebevrediging, kommunikasie en konflikhantering as insette vanuit metateoretiese vlak. In die bogemelde riglyne staan hierdie aspekte egter in die lig van die integrering van die versoeningslewe, die oorwinningslewe en áx $\gamma$ órm in die huweliksverhouding. Die riglyne vir 'n praktykmodel vind sy vergestalting binne die konteks van gemeente-opbou in groepsverband. In die beplanning en strukturering van huweliksorg in groepsverband, moet met die volgende aspekte rekening gehou word:

- Voorsiening moet gemaak word om op 'n gereelde basis byeen te kom. Die opbouende betrokkenheid van die gemeenskap van gelowiges by huweliksopbou en die opbouende betrokkenheid in gevalle van huweliksvervreemding, kan gestimuleer word deur die byeenkom op gereelde basis.

- Pastorale huweliksorg, met die oog op die ontdekking van God se bed seling met die huwelik, is didakties van aard. Naas die didaktiese gerigtheid geld die selfdoenbeginsel: by die behandeling van 'n spesifieke huweliksprobleem of huweliksfaset kan egpare byvoorbeeld vraelyste invul en deur riglyne uit relevante Skrifgedeeltes te verskaf, kan die egpare dan self hul respons op die vraelyste evalueer.

- Pastorale huweliksorg in groepsverband kan as gevolg van die didaktiese aard daarvan nie ongestruktureerd wees nie. 'n Balans moet egter gehandhaaf word tussen gestruktureerde saam-studeer en ongestruktureerde saam-praat ten einde Bybelse waarhede in die huweliksverhouding te integreer.

Die volgende houfpunte, soos in die riglyne vir 'n praktykmodel uiteengesit, kan in verskillende sessies gestruktuteer en beplan word: 
- Die huwelik is 'n gawe van God in sy verbondsgenade. Die doel is die begeleiding van egpare om God se opdrag ten opsigte van die huwelik te ontdek en hul huweliksverantwoordelikheid as geloofsverantwoordelikheid te verstaan. By wyse van Bybelstudie sal veral die betekenis van die beeld van God, die huwelik as 'n samevoeging deur God en die huwelik as 'n verbondsgemeenskap aan die orde moet kom.

- Die huwelik is 'n twee-eenheid in wedersydse aanvulling. Die hoofgedagte is die begeleiding van egpare op die weg van beantwoording aan die Godgewilde bedoeling met die huwelik. Die geleentheid word aan egpare gebied om hulle huweliksverhouding te evalueer en openhartig met mekaar daaroor te praat. Evaluering kan plaasvind deur gebrekkige huweliksverhoudings, byvoorbeeld die vennootskaps-, afhanklikheids- en dwangverhouding van nader te bekyk (vgl. Van Rensburg, 1982:118-126; Louw, 1985b:154-161). Hierna kan Efesiërs 5:21-33 intensief bestudeer en in die groter groep bespreek word.

- In die pastorale huweliksorg is 'n besondere toespitsingspunt die integrering van die selfverloënende liefde in die lief-vir-mekaar-wees (intimiteit). In groepsverband word die wese van die huweliksliefde as selfverloënend (ondanks-liefde) toegelig. Daarna kan egpare apart met mekaar gesels oor vrae soos: walarom het ons getrou? Op watter manier wil ek aan my huweliksmaat vertel dat ek hom/haar liefhet? Is ons liefde tot mekaar ' $n$ bereidheid om in te offer?

- Die begeleiding van die samesyn in die huwelik konsentreer op die versoenende saamleef met mekaar. Aspekte soos vergifnis en opoffering behoort toegelig te word op grond van die nuwe lewe wat Christus verwerf het. Aan egpare kan geleentheid gegee word om in die lig van liefde wat bereid is om op te offer, met mekaar in gesprek te tree oor hinderlikhede in hul onderlinge verhouding.

- In die begeleiding tot saamleef in die huwelik, moet ook die perspektief van oonvinnende saamleef met mekaar in berekening gebring word. Die hoofgedagte is die bereidheid om, gelei en beheers deur die sentrale motief van "uit eerbied vir Christus aan mekaar onderdanig", mekaar se belange te soek. Egpare kan onder meer oor die volgende vraag besin: staan ons as wedywerende partye teenoor mekaar, of is ons huwelik volgens God se bedoeling aanvullend tot mekaar gerig?

- Bybelstudie wat op seksualiteit toespits, het as doel om oor die Skriftuurlike siening van seksualiteit te besin. Die hoofsaak is die afronding en ken van mekaar in die wisselwerkende samehang tussen épos en àyórin. 


\section{Huweliksorg - skep dit die volmaakte huwelik?}

Die huwelik is 'n gemeenskap van twee onvolkome mense. Pastorale huweliksorg beoog nie die versorging van man en vrou tot probleemloosheid in hulle verhouding nie, maar die aanpak van probleme op 'n wyse wat ooreenstem met die nuwe lewe wat Christus vir die gelowige verwerf het. Binne die konteks van gemeente-opbou het pastorale huweliksorg ten doel om egpare te begelei op die weg van groei, uit en na Christus toe.

\section{GEVOLGTREKKINGS}

Op grond van die verkenning van enkele verrykingsprogramme binne psigologiese konteks en die daarstelling van riglyne vir huweliksorg en vir gemeente-opbou, kan die volgende gevolgtrekkings gestel word:

- Die huweliksverrykingsprogramme, wat op die psigologiese groeimodel gebaseer is, bied nie genoegsame Skrifgefundeerde perspektiewe sodat daarmee vir pastorale huweliksorg binne gemeente-opbou volstaan kan word nie.

- Pastorale huweliksorg as paraklese is die begeleiding van egpare op die weg van geloofsgroei sodat man en vrou, in erkenning van God se verbondsheerskappy, hulle huwelik rig op God se bedoeling daarmee.

- Die pastorale versorging van huweliksgenote berus op die kwalitatiewe nuwe bestaan wat vir man en vrou deur die versoening in Christus ontsluit word.

- Die doel van huweliksorg is nie sonder meer die verbetering van 'n goeie huwelik nie, maar omvat ook die parakletiese versorging op die weg van geloofsgroei in 'n versoeningsamesyn en oorwinningsamesyn.

- Die pastorale begeleiding van egpare ten opsigte van die wedersydse soeke na

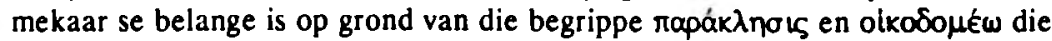
troosvolle en vermanende bediening van die Woord.

- Pastorale huweliksorg is binne die gemeenskap van gelowiges struktureel deel van gemeente-opbou. Pastoraal-ekklesiologies verskil pastorale huweliksorg hierin van huweliksverryking binne psigologiese perspektief deurdat pastorale huweliksorg plaasvind binne die ruimte van die communio sanctonum met as doelwit gemeente-opbou. 
Riglyne vir pastorale huweliksorg binne die konteks van gemeente-opbou

- Pastorale huweliksorg is binne die gemeenskap van gelowiges geïntegreer met die geloofsopbou van medegelowiges - 'n aspek wat groter betekenis het as net die eie.

- Huweliksorg binne die konteks van gemeente-opbou het ten doel om egpare begeleidend te rig op die nuwe lewe wat Christus verwerf het, en in Hom hulle verankerdheid te beleef.

\section{BIBLOGRAFTE}

ADAMS, J.E. 1979. More than redemption. Michigan : Baker Book House.

ADAMS, J.E. 1984. Solving marriage problems. Michigan : Baker Book House.

BALTENSWEILER, H. 1967. Die Ehe im Neuen Testament. Exegetische Untersuchungen über Ehe, Ehelosigkeit und Ehescheidung. Zürich : Zwingli Verlag.

BARNARD, A. 1987. Verryk jou huwelik. Pretoria : Daan Reticf.

BOLKESTEIN, M.H. 1964. Zielszorg in het Nicuwe Testament. Den Haag : Van Keulen.

BRILLENBURG WURTH, G. 1955. Christelijke ziclszorg in het licht der moderne psychologie. Kampen : Kok.

CAPERS, H. \& B. 1976. Transactional tools for use in marriage enrichment programs. (In Otto, HA. ed. Marriage and family enrichment. Nashville : Abingdon. p. 158-169.)

CLINEBELL, HJ. 1970. The intimate marriage. New York : Harper \& Row.

CLINEBELL, HJ. 1981. Contemporary growth therapics. Nashville : Abingdon.

CLINEBELL, HJ. 1982. Growth counseling. Nashville : Abingdon.

FIRET, J. 1968. Het agogisch moment in het pastoraal opireden. Kampen : Kok.

FLOOR, L. 1986. 'n Lamp vir almal in die huis. Pretoria : N.G. Kcrkboekhandel.

GETZ, GA. 1986. The measure of a marriage. California : Regal Books.

HELBERG, J.L. 1976. Openbaringsgeskiedenis van die Ou Testament. Potchefstroom : Pro Rege.

HENDRIKS, H.J. 1987. 'n Teologies-prinsipièle begronding vir die opbou van die gemeente. (In Smuts, AJ., red. Praktiese Teologie in Suid-Afrika 2. Transvaal : N.G. Kerkbockhandel. p.1-25.)

DEWETT, P.K. 1976. Man as male and female. Grand Rapids : Eerdmans.

LINDE, H. 1988. Ons twee is een. Bybelkor se huwelik- en gesinsboureeks. Parow : CTP.

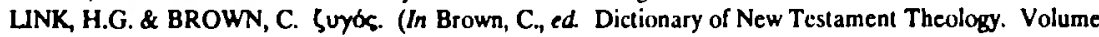
3. Michigan : Zondervan. p. 1160-1165.)

LOUW, DJ. 1983. Versoening in die huwelik - riglyne in dic pastorale bediening. Durban : Butterworth.

LOUW, D. 1985a. Huweliksverryking. Ned. Geref. Teologiese Tydskrif, 26(2):152-172, Maart.

LOUW, DJ. 1985b. Die volwasse huwelik. Durban : Butterworth.

LOUW, DJ. 1986. 'n Teologiese begronding van huweliksverryking. Ned. Gerej. Teologiese Tydskrif. 27(3):258-274, Jul.

MACK, W. 1977. Strengthening your marriage. Phillipsburg : Presbyterian Publishing Co.

MARSTON, P. 1984. God and the family. Eastborne : Kingsway.

MINEAR, P.S. 1977. Images of the church in the New Testamnet. Philadelphia : Westminster.

OTTO, H.A. 1976. Marriage and family enrichment programs: an overview of a movement. (In Otto, HA. ed. Marriage and family enrichment. Nashville: Abingdon. p. 11-27.)

PIETERSE, H.J.C. 1977. Huwelikspastoraat. Pretoria : N.G. Kerkboekhandel.

PIETERSE, HJ.C. 1983. Die hoe egskeidingsyfer vra huweliksverryking. Woord en Daad, 23(248):18-19, Apr.

ROBERTS, J.H. 1983. Die brief aan die Efesiërs. Kaapstad : N.G. Kerk-Uitgcwers. 
ROSSOUW, P.J. 1988. Die herder-kudde-metafoor as vertrckpunt in die pastoraat en die betekenis daarvan vir gemeentebou. (In Smuts, A.J., red. Praktiese Teologie in Suid-Afrika 5. Transvaal : N.G. Kerkboekhandel. p. 14-28.)

VAN DER SCHOOT, E. 1959. Hoofdstukken uit de pastorale psychologie. Utrecht : Bijleveld.

VAN DER WALT, B.J. 1987. Bybelse verrassings oor die vrou. Potchefstroom : PU vir CHO. (Instituut vir Reformatoriese Studie. Studiestuk nr. 228,229.)

VAN RENSBURG, F. 1982. Ongeluk of huwelik? Gebrekkige huweliksverhoudings en die Skriftuurlike buwcliksverhouding. (In Venster op die huwelik. Instituut vir Reformatoriese Studie. Reeks F3: Versamelwerke. Nommer 16. Potchefstroom : PU vir CHO. p. 117-126.)

VENTER, C.J.H. 1986. Gemeente-opbou in die lig van Hebreẽrs. Potchefstroom : PU vir CHO. (Inougurcle redes, nr.103.)

VERSTEEG, J.P. 1980. Oog voor elkaar. Kampen : Kok.

VRIEZEN, Th. C, 1974. Hoofdlijnen der theologie van het Oude Testament. Wageningen : Veenman.

WHEAT, E. 1988. Love life. Basingstoke : Pickering.

ZINKER, J.C. \& LEON, J.P. 1976. The Gestalt perspective: a marriage enrichment program. (In Otto, HA. ed. Marriage and family enrichment. Nashville : Abingdon. p. 144-156.) 
